\title{
THE BRITISH BROADCASTING CORPORATION
}

$\mathrm{T}$ HE annual roport of the British Broadcasting Corporation for the year 1963-64*, which includes those of the Broadcasting Councils for Scotland and for Wales, notes the approval by Parliament of the new Charter and the associated Licence and Agreement botween the Postmaster-General and the Corporation. Under the new Charter, the Corporation's borrowing powers have been increased to $£ 10$ million for temporary banking accommodation, instead of $£ 1$ million, and up to $£ 20$ million for capital expenditure, subject to approval by the Postmaster-General. The Broadcasting Councils for Scotland and Wales have boen given powers in the field of television similar to those which they alroady possessed in radio.

In television, throughout the year, staff and resources wore assembled and deployed in the most complicated single operation in tho history of the Corporation. For the B.B.C. 2 oporation, an entirely new transmitter network of some sixty main stations and a large number of subsidiary stations are being plannod, some with ncw masts $1,250 \mathrm{ft}$. high. In many cases complete now sets of circuits are being provided to carry the more complicated 625-line signals, and new mothods of operation to maintain picture quality are being devised.

Large numbers of staff have had to bo recruited and trained while maintaining present output without any decline in standards, and this has necessitated finding and training 125 producers and many hundreds of supporting staff for programme work. On the technical side, about 900 technical staff had to be recruited and traincd, of whom some 750 specialist and operational engineering staff had already boen rocruited and integrated with existing staff in good time for the opening date. Tho staff employed on March 31, 1964, was 19,722 full time and 1,114 part time, compared with 17,930 and 1,010 , respectively, on March 31, 1963. By November 1963, 154 enginecrs, 176 technical assistants and 189 technical oporators had been recruited, and somo 75 trainees aro at present undergoing the sandwich-course training given to selected staff, while sorne more senior staff are taking courses for the Diploma in Technology.

Much rescarch effort was concerned with various aspects of the introduction of the 625-line television standard for B.B.C.-2, and with problems of ultra-high-frequency transmission. New equipment has been designed for use at tho Television Centre to meet the requirements of 625-line signal distribution, including pulse and timing wave-forms and signal switching, and a range of trans-

* The British Broadcasting Corporation. Annual Report and Accounts for the year 1963-04. Pp. $188+15$ photographs (Cmnd. 2508). (London: H.M.S.O., 1964.) 13s. net. istorized video amplifiers has boen dosigned which combines relative simplicity and the ability to meet all requiroments at a fraction of the cost of valve type of cquipment. Much effort has gone into colour transmission, including an investigation of the threc systems proposed for the transmission of colour signals.

A fully-transistorized froquency-modulated sound translator for very-high-frequency relay stations has been produced which is much casier and cheaper to maintain than the valve-type translators proviously used. The first fully transistorized sound control desks designed by B.B.C. engineers have bcen installed at Broadcasting House, London. The possible future of stereophonic broadeasting in Britain has been reviewed, taking into account the results of the experimental work done, the response to experimental transmissions and the introduction of such broadcasting in the United States and in Canada. The Corporation believes that stereophony can give a worth-while improvement in reproduction, especially of music, and that there is a substential demand for it. No definite plans can be made for its introduction, however, until a decision is reached on the system to be used.

The report emphasizes the need for a substantial reinforcement of the technical resources of the B.B.C.'s external services in the form of rolay stations which will improve signal strength, and enable the British voice to be heard more widely and clearly. The Corporation, which was first in 1950, is now in fourth place in the number of receivers in tho world, following the United States, the U.S.S.R., and China? but West Germany is drawing up steadily. In reputation and effectivencss, however, the Corporation more than holds its own, but the statisties given in the report demonstrate vividly how the rival systems, large and small, regard external broadcasting as of national importance, to be supported and strengthened. During tho year, it is noted that jamming of B.B.C. services to Eastern and Central Europe came to an end, and this probably marks the end of an era in East-West broadeasting.

The failure to reach agreemont on the morits of the three competing systems has deprived the Corporation of the possibility of introducing a colour service before early 1967. Since the report appeared, the International Radio Consultative Commi ${ }_{6}$ tee has met in Vienna, but once again agroement was not reached.

On finance the report rofors to the inadequacy of the licence fees for tolovision and radio and the difficulty in obtaining sufficient income to finance adoquate services, with the result that the Corporation is being forced into extensive borrowing.

\section{THE NATIONAL ELECTRONICS RESEARCH COUNCIL}

$\mathrm{T}$ HE first issue of the N.E.R.C. Review appeared in January*. The journal is a quarterly review of progross in olectronics research published by the National Electronics Research Council.

In a foreword by the chairman of the Council, Earl Mountbatton, readers are rominded that tho National Electronics Research Conncil was formed to fucilitate understanding and oxchange of ideas among all engaged in olectronics rescarch, and that it is only by such exchange

* N.E.R.C. Review, 1, No. 1 (Tanuary, 1965). A quarterly review of progress in electronics rcseareh. Fdited by Graham D. Clifford. Pp. 1-20 + iv. (London: National Electronios Research Council, 1965.) 10s. that any form of co-ordination in research can be achieved in industry, the universities, colloges of advanced tochnology and Governmental research establishments. $\mathrm{He}_{\mathrm{e}}$ goos on to state that the purpose of the review will be to record facts concorning the activities of the Council, to publish briof accounls of such projects as have beon initiated and to comment generally on research achievement and on work in progress.

The longest article deals with the Council's proposnl to investigate the systom known as 'S.D.I.', the selective dissemination of information. Recognizing the importance and urgency of the problem of keeping the rescarch 
worker informed of new work and of developments in his field and the difficulty of minimizing the unnecessary duplication of research, the Council set up a Working Party on Scientific Information. This Working Party was charged with investigating the whole problem of the collection, dissemination and retrieval of information in the field of electronies and making recommendations. Assessing the magnitude of the problem by estimating the annual output of papers and reports of significance to electronice research workers and judging the effectiveness of the published abstracts journals in making the information available, the Working Party concluded that fully published material was satisfactorily indexed for retrospective searching, but that 'semi-published' material (research reports) was poorly served by published indexes. The situation was even less satisfactory in relation to what has been termed 'current awareness'. A research worker trying to make a comprehensive review might have to scan each month more than ten abstracts journals and title lists. Deciding that 'current awareness information' was the most pressing problem the Working Party recommended the investigation of a system of selective dissemination of information in the field of electronics. This system (S.D.I.), which has been in operation in the United States for some years, provides on a large scale a 'personal' current awareness information service to individuals or to groups. In its mechanized form the system matches automatically the coded requirements of the user with a similarly coded index of periodical articles, reports and conference papers. There is provision in the system for 'feedback', by which the user assesses the relevance of the information he receives from the computer to his actual needs.

The Council proposed to the Department of Scientific and Industrial Research--now the Science Research
Council-a three-year project to investigate the effectiveness of a computer-based system of S.D.I. for electronics research workers and has asked for financial support. It is pointed out that this project, although confined to the electronics industry, would provide information relevant to any branch of science and technology and thus be of national interest.

The Projects Committee of the Council, under the chairmanship of Sir Gordon Radley, has reviewed the field in order to identify the areas in which a now or sustained research effort is required. Although no conclusions have, as yet, been reached, it is noted that particular attention is being directed to the following five topics: (1) submillimetric waves; (2) non-linear acoustics; (3) highly directive beams at low frequencies; (4) biological sensors and control systems; (5) basic methods of preparation of now electronies materials.

A short article deals with co-operation between the National Electronies Research Council and the Medical Research Council with which there is a large area of common interest in medical electronic instrumentation. and equipment. The White Fish Authority has a substantial group of electronic research problems and has invited the assistance of the National Electronics Research Council. A further short article describes the proposed development programme.

Under the heading "Electronics Research in British Universities" is an article dealing with the Department of Electronic and Electrical Engineering of the University of Birmingham. The article, which is the first of a series covering individual university departments, utilizes information collected in a survey carried out in 1963 by the Research Committee of the British Institution of Radio Engineers, now the Institution of Electronic and Radio Fngineers.
J. GREIG

\section{TANNING IN THE UNITED STATES TO 1850}

$\mathrm{T}$ HE manufacture of leather is now only a minor industry in all advanced countries, although still important for fulfilling many specialized neods, including shoe manufacture. For some twenty years or more it has been threatened in a number of areas by competition from synthetic products. In the United States to-day thero is a surplus of hides in excess of the requirements of the leather industries, although the world need for leather is greater than the supply.

In the period to which P. C. Welsh refers in his book, Tanning in the United States to $1850 *$, leather was, in contrast, one of the major industries, providing material for harness, saddles, boots and shoes, carriage parts, clothes, gloves, textile machinery and many other essential uses. No substitute was available, so that newly founded colonial communities had rapidly to set up their own tanning facilities, using local tanning materials and local hides. Records of firms, as woll as the material remains of the tanneries, are rapidly disappearing. Amalgamation and competition have eliminated large numbers of tanneries and the records are raroly preserved. It is therefore especially valuable to have Mr. Welsh's carefully documented account of certain aspects of the American industry in the period up to 1850 .

There is ample evidence to show tho widespread distribution of tanneries in the settled areas of tho eastern seaboard, where cattle hides and woolskins were available, by the middle of the seventeenth century. A number of official measures were passed to protect the craft of tanning as well as to attempt to secure good quality in the finished

* Museum of History and Technology, Smithsonian Institution. Tanning in the United States to $1850-a$ Brief History. By Peter C. Welsh. Pp.
ix +99 . (Washington, D.C.: Government Printing Office, 1964.) 1.50 dollars. leather. The manufacturing processes relied almost entirely on manual labour and manual skill, although horses were used for the bark grinding mills. The industrial revolution and the impact of science left the processes almost untouched, up to 1850 and beyond. Even the genius of Sir Humphrey Davy who, in 1802, lectured on tanning, failed to make any impact on the actual processes used. In the absence of mechanization, the uses of steam power in the industry were so limited as to create little demand for the installation of steam engines.

The book provides, by quotation, summary and illustration, an accurate picture of the industry and its processes in this period, together with a detailed account of the various attempts at innovation. These included a successful splitting machine which gave split hides, and the Iess immediately successful French process of Armand Seguin (1794), which aimed at reducing the time of tanning from one to two years to days or at most weeks.

The most detailed section of the book gives an account of the tanneries of Delaware and especially the founding in 1816 of the tanning firm of A. Cordon and Company, through the initiative of the du Pont family, on a site close to their powder factory and cloth mills on the Brandywine. It was intended to exploit the technical ideas originating from the Seguin process, which were expected to givo considerable commercial advantages over the normal slow proeess. Alexandre Cordon de Sandrans had gone to the United States in 1815 as secretary to du Pont de Nemour, and it was he who managed the tannery. The leather from the shorter process does not appear always to have been of satisfactory standard and the commercial management by Cordon was not adoquate to the problems involved. The period was one of low 